\title{
To fish or not to fish? Resource degradation and income diversification in Benin
}

\author{
NIK STOOP \\ Centre for Institutions and Economic Performance, University of Leuven, \\ Waaistraat 6, 3000 Leuven, Belgium; Institute of Development Policy and \\ Management, University of Antwerp; and Research Foundation Flanders. \\ Email:nik.stoop@kuleuven.be
}

ROMAIN HOUSSA

Centre for Research in Economic Development \& Centre for Research in Finance and Management, University of Namur; and Centre for Economic Studies, University of Leuven.

Email:romain.houssa@unamur.be

\section{MARIJKE VERPOORTEN}

Institute of Development Policy and Management, University of Antwerp; and Centre for Institutions and Economic Performance, University of Leuven.

Email: marijke.verpoorten@uantwerpen.be

Submitted 24 October 2014; revised 1 September 2015, 14 December 2015; accepted 22 December 2015; first published online 12 February 2016

\begin{abstract}
The authors study the impact of natural resource degradation on income diversification in Beninese fishing communities. Using survey data and econometric analysis, they show that fishermen are more likely to diversify their income when the degradation of the fish stock is more severe. However, the level of income diversification that they find is surprisingly low and far from sufficient to relieve the stress on the lakes. The latter relates to low levels of formal education among fishermen and the unregulated use of highly productive, but damaging, fishing gear. These two factors result in a high return to fishing relative to non-fishing activities, even amid degradation.
\end{abstract}

The authors thank participants at seminars and conferences in Leuven (LICOS seminar and EAAE workshop), Oxford (CSAE conference), Antwerp (IOB research day) and Berlin (DIW) for helpful comments and suggestions. This research was funded by the Research Foundation Flanders (FWO) - Grant No. S_2/2_2012 and F_6/12_2010, and by the Centre for Institutions and Economic Performance (LICOS). Romain Houssa acknowledges financial support from ACROPOLIS (Academic Research Group for Policy Support). The authors are grateful to Pierre Midogbo Gnohossou for making his bio-index available and to LICOS PhD students for assistance in data cleaning. The usual disclaimer applies. 


\section{Introduction}

The World Commission on Environment and Development (WCED) coined the idea that poor people are stuck in a poverty-environment trap. In its report 'Our common future', the commission stated that poor people in developing countries are left with little choice but to overexploit the available natural resources in order to survive (WCED, 1987). The subsequent natural resource degradation further impoverishes them, making them even more reliant on the available natural resources.

In reality, the relationship between poverty and the environment is more complex, and poor people are not doomed to depend on ever-decreasing natural resources. Dasgupta (1993: 477-511), for instance, develops a model in which, instead of living on the exploitation of common-property resources, rural households have alternatives in terms of labour market participation. The attractiveness of these alternatives is directly linked to the productivity of common-property resources. Specifically, a degradation of common-property resources reduces the revenues obtained from them, thus lowering the reservation wage to engage in outside employment and stimulating resource users to reallocate their labour away from resource-dependent activities. In the extreme case, this reallocation is complete, but in many cases (including our case study) some resource dependence remains, and reallocation essentially implies income diversification. Hence, we refer to Dasgupta's hypothesis as the income diversification hypothesis. $^{1}$

Barbier (2010) develops a theoretical model in which he shows that this diversification hypothesis holds, provided that outside options are accessible and markets operate well. In the absence of well-functioning markets for labour, credit or products, a poverty-environment trap may loom at the horizon, in which degradation continues, further impoverishing communities and exacerbating market failures.

Understanding the impact of resource degradation on income diversification is important, not only because diversification directly affects income and thus poverty (Barrett et al., 2001), but also because diversification may alleviate environmental degradation (Reardon and Vosti, 1995; Forsyth et al., 1998; Swinton et al., 2003; Ellis and Allison, 2004). The latter may occur directly through a diminished use of natural resources, or indirectly because lower resource dependence has been shown to play a role in the emergence of successful common-pool resource management systems (Cinner et al., 2013; Ernst et al., 2013; MacNeil and Cinner, 2013).

In this paper, we examine if and to what extent natural resource degradation induces artisanal fishermen and fishmongers in Benin to reallocate their labour away from resource-dependent activities. The (male) fishermen and (female) fishmongers in our study belong to communities located at the three main coastal lakes of Benin. The communities are remote and

${ }^{1}$ Panel A of figure 1 graphically presents the hypothesized relationship between degradation and income diversification that follows from this proposition. The reservation wage must as a minimum be offered if an individual is to accept a job in the labour market (Dasgupta, 1993: 479). 
Panel A: Dasgupta (1993)

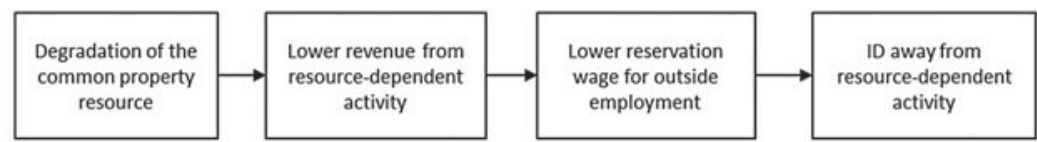

Panel B: Relationship between degradation and income diversification in our sample area
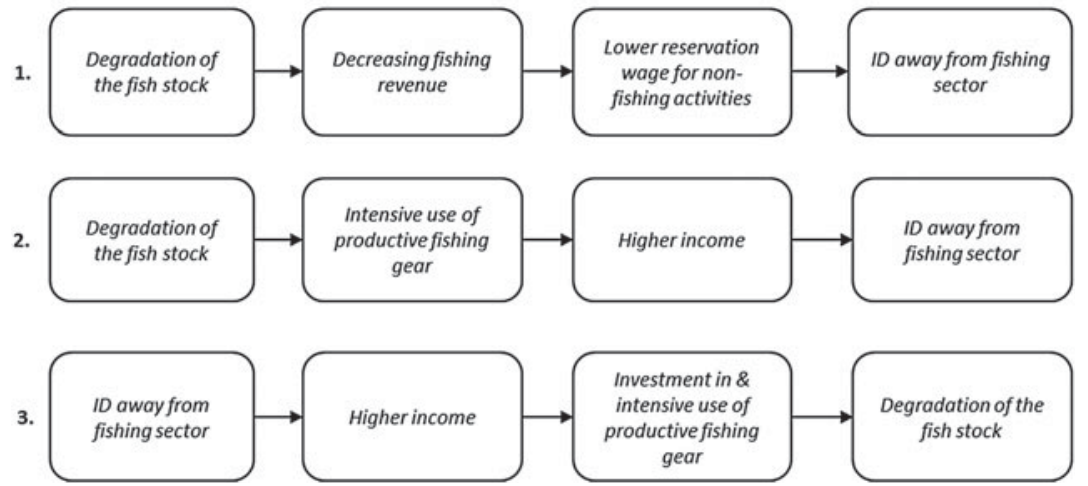

Figure 1. Relationship between degradation and income diversification (ID)

Notes: Panel A represents the hypothesized relationship between the degradation of common property resources and income diversification that follows from Dasgupta's (1993: 477-511) model of labour market participation. Panel B offers an overview of the channels that could yield a positive relationship between natural resource degradation and income diversification in our sample area. Channel 1 follows from Dasgupta's (1993) model. Channels 2 and 3 crucially depend on non-convexities in production, such as fixed costs and missing credit markets - if not, earning higher incomes would not be a necessity to invest in outside options or productive fishing gear. In addition, both channels 2 and 3 embody a failure of common-pool resource management as they entail the intensive use of productive but highly damaging fishing instruments.

characterized by underdeveloped labour and credit markets. In the absence of effective common-pool resource management, highly productive but damaging fishing gear has proliferated. By now, resource degradation has strongly reduced the fish stock available to these communities, threatening their livelihoods (Gnohossou, 2006; Niyonkuru and Lalèyè, 2010). In our empirical framework, we disentangle three channels which could potentially yield a positive relationship between resource degradation and income diversification in our sample area (panel B of figure 1 offers a graphical representation). The first channel follows from Dasgupta's (1993) model: the degradation of the fish stock decreases fishing revenues, which lowers the reservation wage for non-fishing activities ${ }^{2}$ and stimulates labour reallocation away from the fisheries sector. The other two channels are instead driven by the ownership of highly productive but damaging

2 In the context of our study, we define 'reservation wage' as the minimum wage that a fisher is willing to accept in order to substitute labour from fishing activities with outside employment. 
fishing gear. Channel 2 assumes that fishermen who own such gear have higher incomes, allowing them to invest more easily in outside options. A third channel assumes that non-fishing activities generate the income needed to invest in more productive but damaging fishing gear, resulting in higher degradation.

Our study relates to a growing literature which analyses the state of common-pool resources as a determinant of employment decisions among households in developing countries. For instance, Barbier (2007) finds that mangrove deforestation in coastal communities of Thailand encourages female labour participation in outside employment. Pascual and Barbier (2006, 2007) show that declining soil fertility in Mexico induces income diversification for wealthier households, but encourages poorer households to clear more forest for agricultural use. We contribute to this empirical literature, first by providing a case study on African small-scale fisheries, thereby studying a context in which the quality of institutions for common-pool resource management is critical, as fishermen can use a wide variety of fishing gear, including gear that greatly aggravates natural resource degradation. Secondly, unlike previous studies, we empirically address the endogeneity of resource degradation. In particular, we use an instrumental variables (IV) approach to isolate the exogenous variation in resource degradation. This allows us to deal with the two-way causality between degradation and income diversification, and study the causal impact of degradation on income diversification away from the fisheries sector. Furthermore, although we apply a quantitative method to study the impact of degradation on income diversification, our analysis builds on several months of fieldwork in the study area which generated less tangible although equally valuable qualitative observations, helping immensely in the design of our econometric framework and interpretation of estimation results.

In what follows, we first provide a background on Benin's inland fisheries sector. Next we present our data and the econometric framework. The final sections discuss the results and potential policy implications.

\section{Benin's inland fisheries}

Benin is a small country in West Africa (figure 2). About half of its 9 million inhabitants live in the southernmost part of the country, close to the coastal lakes and lagoons. The fisheries sector is of great importance to both national and rural economic development. Fish is the main source of animal protein consumed in the country and, in 2008, approximately 600,000 people were employed in the fisheries sector (USAID, 2007; FAO, 2008).

Inland fisheries dominate, accounting for 75 per cent of Benin's fisheries production (FAO, 2008). The majority of fish are caught in the three main coastal lakes: Lake Nokoué $\left(150 \mathrm{~km}^{2}\right)$, Lake Ahémé $\left(85 \mathrm{~km}^{2}\right)$ and PortoNovo lagoon $\left(35 \mathrm{~km}^{2}\right)$. Lake Nokoué and Porto Novo lagoon are connected by the Totché Channel, making it the largest water body in the country. Two other channels connect the lakes to the Atlantic Ocean. These connections are vital to the ecosystem, as the inflow of marine water creates seasonal 

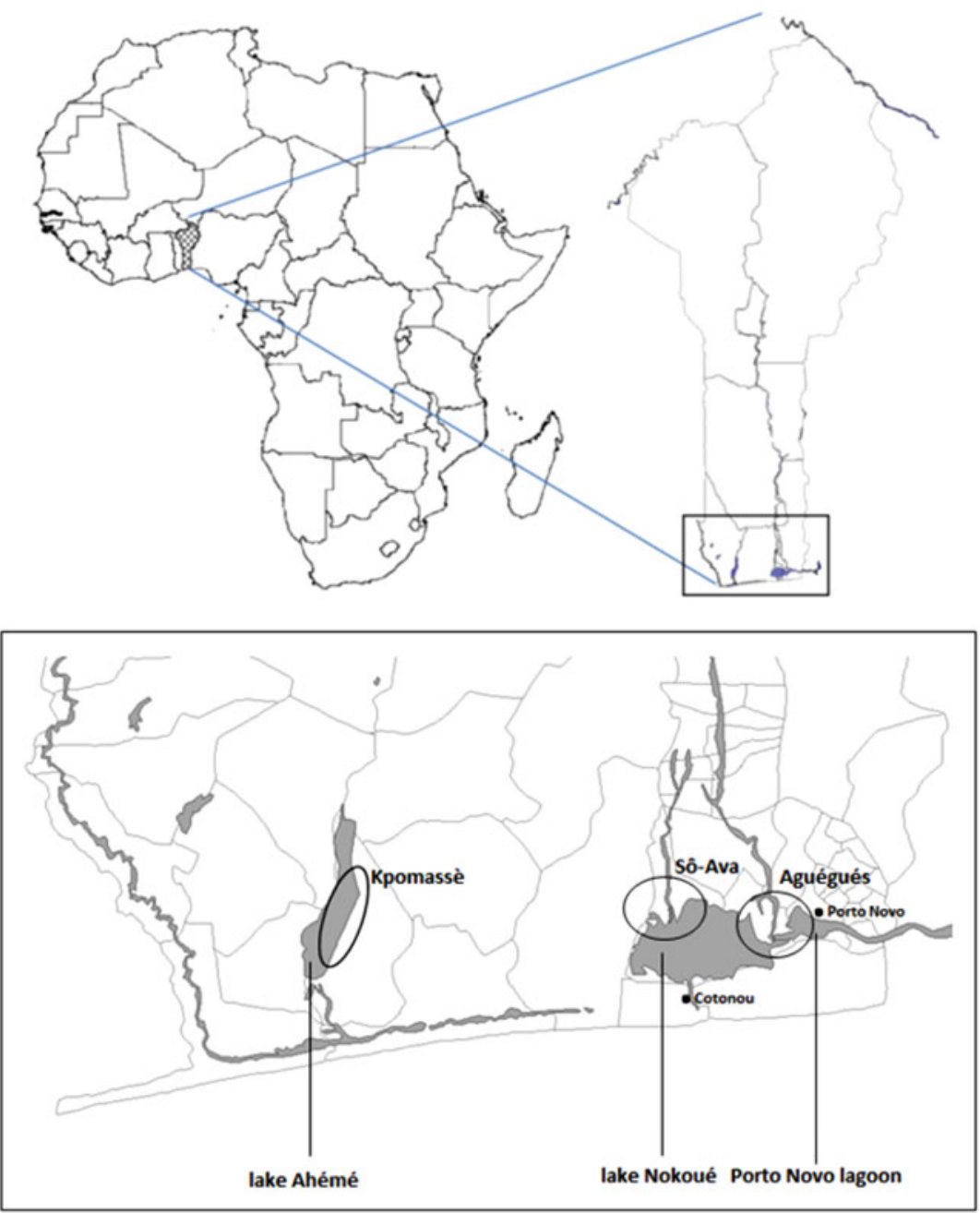

Figure 2. Location of the sampling area and the three main lakes of southern Benin Notes: Our sample area comprises three communes (Kpomassè, Sô-Ava and Aguégués), located at the three main lakes of Benin (Lake Ahémé, Lake Nokoué and Porto Novo lagoon).

variations in the salinity, temperature and oxygen level of the water, which promote diversity and the reproduction of aquatic fauna and flora (e.g., Amoussou, 2004).

Villages are located along the border of the lakes and on the water surface. They are inhabited by different ethnic groups which strongly depend on the fisheries sector for their livelihoods. In the past few decades, the lakes have experienced dramatic environmental degradation leading to a 
loss of biodiversity and a decline of the fish stock (Amoussou, 2004; Allan et al., 2005; Gnohossou, 2006; USAID, 2007; FAO, 2008).

The socio-economic changes associated with the colonization of Benin (1894-1960) gradually increased pressure on the lakes. The emergence of markets and transport systems enhanced the economic value of fishery resources beyond subsistence level, with a consequent increase in the number of fishers (Dangbégnon, 2000). In addition, both the number of fishers and the demand for fish increased due to high population growth as well as migration flows to the coastal region.

The colonization, as well as the increased monetization and commercialization of the economy, also marked the breakdown of the traditional natural resource management system which was embedded in the Voodoo religion. This system prevented overfishing and the use of damaging fishing instruments through a set of rules and sanctions. The rules were enforced by local spiritual leaders who gained legitimacy from their close association with the ancestors (Dangbégnon, 2000; USAID, 2007; Briones Alonso et al., forthcoming). The colonization and subsequent promotion of monotheistic religions in Benin reduced the influence of Voodoo and undermined the authority of local spiritual leaders.

In recent years, new management institutions were introduced, but they have not been able to effectively regulate fishing activities due to problems with monitoring and enforcement (Maarleveld and Dangbégnon, 1999; Dangbégnon, 2000; USAID, 2007; Briones Alonso et al., forthcoming). ${ }^{3}$ The lack of effective management gave way to the introduction of highly yielding but damaging fishing instruments from the 1960s onward (Dangbégnon, 2000). Especially the increased use of acadja and konou has contributed to the problem of overfishing and resource degradation (USAID, 2007; FAO, 2008; Niyonkuru and Lalèyè, 2010). Acadja resembles a fishing pond. It is constructed by placing wooden branches in the lake and fencing them with fishing nets (USAID, 2007). Konou is also a fixed fishing installation, with fine-mesh nets which are set in such a way that fish get trapped. Both instruments are more expensive to acquire than other, less productive, instruments. The acadja can be purchased or inherited, but the market for acadja is informal (there are no legal titles) and very thin, as it is constrained by the size of the lakes which are already saturated with acadja. Figure A1 (in the online appendix available at http:/ /journals.cambridge.org/EDE) provides a visual representation of these instruments, as well as detailed information on their contribution to the resource degradation in our sample area.

3 The new management institutions are situated both at the national and the local level. The way national regulations are implemented de facto depends on the local context. As such, at Lake Ahémé, where degradation is most severe, the lake-level fishing committees are much less lenient towards the use of highly productive but damaging fishing gear. A detailed discussion of the fishing committees and their operation can be found in (Briones Alonso et al., forthcoming). 
Table 1. Village-level self-reported degradation (\%)

\begin{tabular}{lrllll}
\hline Ahémé & \multicolumn{2}{c}{ Nokoué } & \multicolumn{2}{c}{ Porto Novo } \\
\hline Adja Tokpa I & 82 & Agoundankomey & 68 & Aholoukome & 37 \\
Segbohoue I & 100 & Sokomey & 42 & Akpoloukome & 73 \\
Segbohoue II & 97 & Tohokomey & 19 & Dogodo & 98 \\
Gbetozo & 91 & Gbetigao & 44 & Djigbekome & 32 \\
Lokogbo I & 100 & Todo & 60 & Houndekome & 95 \\
Tokpa-Dome II & 95 & Vekky Daho & 29 & Kindji & 91 \\
Total & 93 & Total & 47 & Total & 70 \\
\hline
\end{tabular}

Notes: The reported percentages indicate the village-level share of respondents who indicated that the fish stock decreased over the 10 years prior to the survey.

\section{Data and descriptive statistics}

\subsection{Survey design}

The data were obtained from a survey among 418 households, implemented in the period March-July 2009. The sample was randomly selected from Benin's 2006 fisheries census and stratified geographically. The sample area comprised 18 villages in three communes (Kpomasse, So-Ava and Aguesgues), which are located at the three main lakes of Benin (figure 2). We collected recall information on economic activities in the 12 months prior to the interview as well as on the evolution of economic activities for the period 2002-2009. The full survey sample includes 1,873 individuals aged 15 years or older, who individually responded to the questions.

\subsection{Natural resource degradation}

We asked fishermen and fishmongers about their opinion on the evolution of the fish stock: 'In your opinion how did the fish stock evolve in the past 10 years?'. Answer categories included (1) increased, (2) decreased, (3) unchanged, (4) don't know. The large majority of our respondents (66 per cent) report a decreasing fish stock.

Our main measure for local natural resource degradation is the villagelevel share of respondents who report a decreasing fish stock (table 1). We are confident that this is a reasonable proxy. First, the variation of responses across lakes makes sense as the effects of degradation are more apparent in smaller lakes (Ahémé and Porto-Novo), which start off with less abundant natural resources and are more prone to silting. Second, self-reported degradation is higher in areas where the lake is more shallow - making it more prone to silting, low oxygen levels, poor water circulation and higher levels of salinity (Gnohossou, 2006). ${ }^{4}$ Lake Ahémé stands out in this respect, as it has a maximal depth of only $2.35 \mathrm{~m}$. In addition, with a length

${ }^{4}$ In addition, where the lake is shallow, one can find the largest human settlements (on pile villages). Gnohossou (2006) finds that pollution peaks around these villages, probably because of human waste. He also finds that the lower the water quality, the lower the presence of micro-species that constitute the feed of fish. 
of $24 \mathrm{~km}$ inwards, it touches on many agricultural land parcels, in which erosion exacerbates the problem of silting (Amoussou, 2004). Finally, the data reported in table 1 are in line with existing studies on aquatic resource degradation in the sample area (e.g., Atti-Mama, 1998; Roche International, 2000; Cledjo, 2006).

\subsection{Income diversification}

We define five different income sectors: the fisheries sector, agriculture and livestock keeping, petty trade, other self-employment in the non-farm sector (e.g., barbers, tailors, etc.) and wage employment (e.g., government officials or people employed by an NGO or private company).

The fisheries sector is by far the most important sector, both in terms of employment and contribution to annual income. The large majority (86 per cent) of the economically active sample remains at least partly employed in the fisheries sector, and at every lake the sector accounts for about 80 per cent of annual income. Fishing activities are marginally more important at Lakes Ahémé and Nokoué (84.7 and 82.3 per cent of annual income, respectively) compared to Porto Novo (77.9 per cent). Petty trade and self-employment prevail at Porto Novo, while agriculture and livestock keeping are mostly practised at Lake Ahémé, where people have more access to farmland.

Based on the 12-month recall module, we construct two standard measures of income diversification. First, we derive the number of income sources. Second, we construct the Herfindahl index of diversification which takes into account both the number of income sources and the income share derived from each source (Barrett and Reardon, 2000). Among the existing specifications of the index, we use the complementary proportion (1-proportion) such that a higher index indicates stronger income diversification. ${ }^{5}$ We are specifically interested in the effect of resource degradation on the reallocation of labour away from resource-dependent activities. As the large majority of our sample is engaged in the fisheries sector, both measures of income diversification essentially capture the diversification away from the fisheries sector. To make this very explicit, our first measure will directly consider the number of activities outside the fisheries sector.

Table 2 confirms that income diversification is rather limited in the sample area. People on average derive their income from 1.26 sources, of which only 0.4 sources are outside the fisheries sector. The average Herfindahl index measures 0.06 - with the index ranging from 0 to 0.5 .

\subsection{Degradation and income diversification}

A bivariate analysis shows that four factors correlate significantly with the level of income diversification (table 2). First, income diversification is more

5 The index is defined as $H=1-\sum_{i=1}^{N}\left(S_{i}\right)^{2}$, where $S_{i}$ is the income share of activity $i$. It ranges from zero, indicating that all income is generated by a single income source, to $1-\left(\frac{1}{N}\right)$, indicating that all income sources equally contribute to total income. 
Table 2. Mean income diversification

\begin{tabular}{|c|c|c|c|}
\hline & $\begin{array}{l}\text { No. of income } \\
\text { sources }\end{array}$ & $\begin{array}{c}\text { No. of income sources outside } \\
\text { the fisheries sector }\end{array}$ & $\begin{array}{l}\text { Herfindahl } \\
\text { index }\end{array}$ \\
\hline \multicolumn{4}{|l|}{ Lake } \\
\hline Ahémé & 1.35 & 0.42 & 0.10 \\
\hline Nokoué & $1.27^{* * *}$ & $0.40^{* * *}$ & $0.04^{* * *}$ \\
\hline Porto Novo & $1.16^{* * *}$ & $0.35^{* * *}$ & $0.05^{* * *}$ \\
\hline \multicolumn{4}{|c|}{ Self-reported degradation } \\
\hline No & 1.15 & 0.32 & 0.03 \\
\hline Yes & $1.30^{* * *}$ & $0.43^{* * *}$ & $0.08^{* * *}$ \\
\hline \multicolumn{4}{|l|}{ Literate } \\
\hline No & 1.23 & 0.36 & 0.06 \\
\hline Yes & $1.35^{* * *}$ & $0.52^{* * *}$ & $0.09^{* * *}$ \\
\hline \multicolumn{4}{|c|}{ Owns acadja/konou } \\
\hline No & 1.33 & 0.45 & 0.08 \\
\hline Yes & $1.21^{* * *}$ & $0.36^{* * *}$ & $0.05^{* * *}$ \\
\hline Total & 1.26 & 0.40 & 0.06 \\
\hline
\end{tabular}

Notes: ${ }^{* *} p<0.01 ;{ }^{* *} p<0.05 ;{ }^{*} p<0.1$. The significance levels of the differences in means were obtained from an ANOVA test.

widespread at the smallest water body (Ahémé). Second, income diversification is significantly higher for individuals who reported a degradation of the fish stock compared to those who did not. Third, the data show that literate individuals have a higher level of income diversification compared to illiterate individuals. Finally, individuals who do not own the most productive fishing instruments (acadja or konou) are more likely to diversify their economic activities.

Despite the degradation of the fish stock, the majority of individuals thus remain extremely dependent on fishing activities. This could be the case because fishing is, on average, still more profitable than other income activities, and especially so for the owners of acadja or konou. Figure 3 illustrates the relative profitability of fishing activities. The figure clearly shows that fishing is by far the most profitable activity for those who own acadja or konou. For the average fisherman who does not own these productive instruments, fishing is only marginally more profitable than self-employment and petty trade.

The above statistics provide a snapshot of cross-correlations at one point in time. We are also interested in the evolution of income diversification over time. On average, 7.5 per cent of our sample reported having abandoned an economic activity in the period 2002-2009. At every lake, fishing was the main abandoned activity. At Lake Ahémé, 92 per cent of individuals who abandoned an activity were fishermen, compared to 73 and 52 per cent at Lake Nokoué and Porto Novo lagoon, respectively. Over the same period, 14 per cent of our sample reported having started a new activity. There was a strong proportional growth in non-fisheries sectors at all three lakes. Overall, the number of individuals involved in 

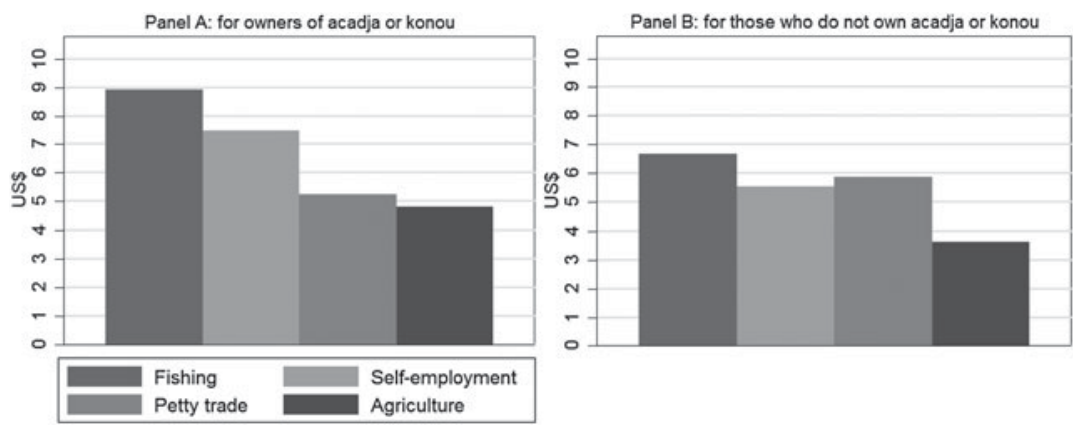

Figure 3. Average daily income (US\$), by sector

Notes: The graphs represent the average daily income (in US\$) for the following income categories (in order of appearance): fishing, self-employment, petty trade and agriculture. Wage employment is not considered due to the low number of observations $(\mathrm{n}=4)$. A t-test indicates a statistically significant difference in average daily income for fishing ( $p$-value $=0.00$ ) between panels $A$ and $B$. As the use of acadja and konou is prohibited at Lake Ahémé, these graphs only include observations from Lake Nokoué and Porto-Novo lagoon.

agriculture, self-employment and petty trade grew by 20, 34 and 75 per cent, respectively.

Regarding the motives for diversifying income towards non-fishing activities, the large majority of respondents (64 per cent) reported a decline in the relative profitability of fishing activities: 26 per cent indicated that non-fishing activities have a higher return, while 38 per cent mention other reasons which directly affect the reservation wage of fishermen (the degradation of the fish stock (11 per cent), the ban on shrimp exports to the EU (15 per cent) ${ }^{6}$ and a lack of access to productive fishing instruments (12 per cent)). We also find that in villages with higher levels of self-reported degradation, daily fishing revenues were significantly lower in 2009, and a larger share of the population had abandoned fishing activities in the period 2002-2009 in favour of the non-fisheries sector (see table A1 in the online appendix).

In sum, the descriptive evidence is in line with Dasgupta's (1993) hypothesis that the degradation of the fish stock has led to a decrease in fishing revenues and thus lowered the reservation wage to engage in non-fishing activities. This is especially the case for individuals who do not possess the most productive fishing instruments. We now move to an econometric analysis to verify whether these relations also hold when controlling for potentially confounding factors.

${ }^{6}$ In 2003, a ban on shrimp exports to the EU was imposed due to a lack of compliance with food standards (Houssa and Verpoorten, 2015). 
4. Econometric framework

Our empirical model reads:

$$
\begin{aligned}
I D_{i h v}= & \alpha_{0}+\alpha_{1} \text { degradation }_{v}+X_{i h v}^{\prime} \Omega+W_{h v}^{\prime} \Delta+\alpha_{2} \text { pop }_{v}+\alpha_{3} \text { dist }_{v} \\
& +\alpha_{4} \text { Nokoué }_{v}+\alpha_{5} \text { Porto Novo }_{v}+\varepsilon_{i h v},
\end{aligned}
$$

where $i$ indexes individuals, $h$ households and $v$ villages. $\mathrm{ID}_{i h v}$ denotes income diversification at the individual level; $\alpha_{0}$ is a constant; degradation ${ }_{v}$ denotes village-level natural resource degradation; $X_{i h v}$ and $W_{h v}$ are vectors of individual- and household-level covariates; $\operatorname{pop}_{v}$ denotes total village population; dist $_{v}$ represents the village-distance to the closest town; Nokoué $_{v}$ and Porto Novo $v$ represent lake dummies (Lake Ahémé is the base category), and $\varepsilon_{\mathrm{ih} v}$ is the standardized error term. ${ }^{7}$ The determinants of the number of income sources are estimated with an ordered probit model, while we estimate the determinants of the Herfindahl index with a tobit model. We estimate these models on the economically active sample, which comprises 1,220 individuals.

\subsection{Individual-level controls}

We study income diversification at the individual level because the financial spheres of husband and wife in Benin are largely disconnected, i.e., expenditure and investment decisions are based on individual, rather than common, budgets and preferences (LeMay-Boucher and Dagnelie, 2012). ${ }^{8}$ Individual-level control variables include gender, age, education, ethnicity and religion.

Gender is an important determinant in the choice of economic activities, mainly due to social norms or because of differences in physical strength (Ellis, 1999; Barrett et al., 2001; Lanjouw et al., 2001; Smith et al., 2001). In Benin's coastal fisheries, the actual fishing is reserved for men while women operate as small or intermediate traders of fish, or process the catch (by smoking or drying it). In their role as fishmongers and processors, women may also see their revenues being threatened by the degradation of the fish stock, and thus be pushed to diversify their activity portfolio. Age may also play a role in the choice of economic activities. Using the konou, for instance, requires physical strength which decreases with age. Young men also tend to be more mobile, which may enhance their opportunities for income diversification. Older men, on the other hand, may

${ }^{7}$ We allow for within-household dependence in the standard errors by estimating cluster-robust standard errors (see Moulton (1990) on the use of corrected standard errors).

${ }^{8}$ LeMay-Boucher and Dagnelie (2012) analyze individual-level income and expenditure data from Beninese couples and find that not only do husbands and wives not pool their incomes, but that more than three out of four individuals are unable to estimate their spouse's income. These findings are in line with other economic intra-household studies of West Africa (e.g., Udry, 1996; Doss, 2001), and confirm numerous anthropological accounts from West Africa that conclude that husband and wife are secretive and individually allocate their personal income to private and public goods (e.g., Clark, 1994; Falen, 2003; Mandel, 2006). 
have been able to acquire acadja on a first-come, first-served basis, leaving younger men empty handed until they inherit one. Educational attainment is another important determinant of non-farm earnings and self-employment in rural Africa (Barrett et al., 2001). In our setting, education may increase productivity both in fishing and non-fishing activities, and can improve access to non-fishing activities. We measure educational attainment by an indicator variable which equals 1 if an individual is able to read a small note and write numbers. ${ }^{9}$ We control for ethnicity as some groups are traditionally more involved in fishing activities than others, due to different times and patterns of settlement around and on the lakes (Pliya, 1980). We include dummy variables for the three most prevalent ethnicities (i.e., Goun, Houedah and Tofin) which jointly account for 91 per cent of the sample. The remaining 11 smaller ethnicities form the base category. Finally, we control for religion by including an indicator variable which equals 1 if an individual is a Voodoo adherent. As previously explained, the traditional natural resource management system was embedded in the Voodoo religion. The Voodoo governance system prevented overfishing and the use of damaging fishing instruments through a set of rules and sanctions (Briones Alonso et al., forthcoming). Voodoo adherents may therefore be less likely to use acadja or konou.

\subsection{Household-and community-level controls}

Although budgets are separately managed by husband and wife, the size and structure of a family may still influence the activity portfolio of its members. We therefore include the size and the dependency ratio of the household as possible determinants of income diversification. The dependency ratio is calculated as the ratio of the number of inactive individuals to the number of active individuals in the household. We further control for the ownership of high-yielding fishing gear (acadja or konou).

Finally, community-level covariates may be important. The population size of a village may influence the opportunities for engaging in outside employment, and may affect the potential gains from both fishing and nonfishing activities through the availability of markets. The village distance to the nearest town may also influence outside employment opportunities and occupational choices. Lake dummies are included to control for the different characteristics and location of the lakes. ${ }^{10}$

\subsection{Endogeneity of degradation}

Our measure for natural resource degradation may be endogenous. First, there may be reversed causality: income diversification may affect degradation. After all, if people choose to diversify their activity portfolio, this may protect the fish stock from degradation. This endogeneity problem is exacerbated because self-reported degradation is subjective and

${ }^{9}$ A substantial fraction of individuals who attended school for several years is still illiterate (see table A2 in the online appendix). As such, the literacy indicator is a better proxy for human capital than the years of schooling an individual obtained.

10 Table A3 in the online appendix provides an overview of descriptive statistics for the control variables. 
likely depends on individual characteristics which could also be related to income diversification. Second, in the absence of well-functioning credit markets, a positive relationship between degradation and income diversification could be driven by the ownership of high-yielding fishing gear: channels 2 and 3, presented in figure 1, both imply that individuals who own productive fishing gear are more likely to diversify their income. If either channel holds, not controlling for the ownership of high-yielding fishing gear would give rise to an omitted variable bias, making our degradation measure endogenous.

We deal with these endogeneity issues in two ways. First, we use an IV approach to account for reversed causality. Secondly, we assess the likelihood of channels 2 and 3 .

\subsubsection{Instrumental variables approach}

The three lakes in our sample are so-called estuaries, meaning that they are subject both to marine and riverine influences. During the rainy season, the rivers grow and fill the lakes with freshwater; during the dry season, rivers dry up and seawater enters the lakes. We instrument our degradation measure with the village-distance to the closest influx of water. For the villages at Lake Ahémé this equals the distance to the channel connecting the lake with the ocean. For the villages at Lake Nokoué and Porto-Novo lagoon, it is the distance to the river entering the lakes from the North (see figure 2). The instrument is relevant as it is highly correlated with self-reported degradation $\left(0.43^{* * *}\right)$. Several factors underlie this positive correlation. First, the further from an influx of water, the more shallow the lake is - which makes it more prone to silting, low oxygen levels, poor water circulation and higher levels of salinity (Gnohossou, 2006). ${ }^{11}$ Secondly, acadja can only be placed in areas where the lake is shallow. Finally, large fishing nets such as konou are usually placed close to an influx of water, thereby leaving fewer resources for fishermen further downstream.

In a first step, we estimate village-level degradation by regressing it on the set of included instruments and the distance to the closest influx of water. In a second step, we estimate individual-level income diversification by regressing $I D_{i h v}$ on degradation $v_{v}$, estimated in the first step, and the other explanatory variables. The IV procedure is given by the following equations:

$$
\begin{aligned}
\text { degradation }_{v}= & \beta_{0}+\beta_{1} \text { influx }_{v}+X_{i h v}{ }^{\prime} \Omega^{\prime}+W_{h v}^{\prime} \Delta^{\prime}+\beta_{2} \text { pop }_{v}+\beta_{3} \text { dist }_{v} \\
& +\beta_{4} \text { Nokoué }_{v}+\beta_{5} \text { Porto Novo }_{v}+\mu_{i h v}, \\
I_{i h v}= & \alpha_{0}^{\prime}+\alpha_{1}^{\prime} \text { degradation }_{v}+X_{i h v}{ }^{\prime \prime} \Omega^{\prime \prime}+W_{h v}{ }^{\prime} \Delta^{\prime \prime}+\alpha_{2}^{\prime} \text { pop }_{v} \\
& +\alpha_{3}^{\prime} \text { dist }_{v}+\alpha_{4}^{\prime} \text { Nokoué }_{v}+\alpha_{5}^{\prime} \text { Porto Novo }_{v}+\varepsilon_{i h v},
\end{aligned}
$$

11 At Lake Nokoué, we find a negative correlation of $-0.59^{* * *}$ between depth of the lake and distance to the closest influx of water (we don't have detailed information about depth for the other two lakes). 
The results of the first-stage estimation (equation (2)) confirm the relevance of our instrument: distance to the closest influx of water is positively and significantly related to degradation and the $F$-test of the first-stage estimation equals $23.78^{* * *}$ (see column 3 in table A4 of the online appendix). When comparing the estimates of equations (1) and (3), we find qualitatively similar results, although a significant difference in quantitative terms between the estimated coefficients on degradation. This indicates there is indeed endogeneity, and an IV approach is more appropriate. Consequently, we present IV results in the remainder of this article. The equation (1) estimates are available in table A4 (online appendix).

\subsubsection{Likelihood of channels 2 and 3}

Channels 2 and 3 necessitate a positive correlation between the ownership of acadja or konou and income diversification. If channel 1, i.e., 'the reservation wage channel', holds, we expect a negative correlation: the use of productive fishing gear renders reservation wages more robust to a degradation of the fish stock, thus spurring less income diversification among its owners. The estimated coefficients on the ownership of these fishing instruments will therefore give a first indication of these channels. In addition, we can assess the likelihood of channels 2 and 3 by estimating two model specifications - one in which we control for the ownership of acadja or konou, and one in which we do not. If either channel holds, we would find a significant change in the coefficient estimates on degradation between the two specifications (because of omitted variable bias).

\section{Main results}

Our results are in line with Dasgupta's (1993) hypothesis: the degradation of the fish stock correlates positively and significantly with income diversification. This result is robust across both measures of income diversification. The data in table 3 indicate that a 10 per cent increase in village-level self-reported degradation increases a fisherman's likelihood of having an income source outside the fisheries sector by 12.19 percentage points, while it increases the Herfindahl index by 0.16 units. The likelihood of having one, two or three income sources outside the fisheries sector increases respectively with 4, 3 and 5 percentage points (although the latter change is not statistically significant). The results further indicate that literate fishermen are 8 percentage points more likely to have an income source outside the fisheries sector. Tables A5 and A6 in the online appendix show the estimated marginal effects for all control variables.

Turning to the alternative channels: the ownership of acadja or konou is negatively related to income diversification (although the coefficient is only statistically significant with respect to having three income sources outside the fisheries sector, see panel A of table 3). This provides first evidence against channels 2 and 3 of figure 1, which both imply a positive and significant coefficient. When controlling separately for the ownership of these fishing instruments, we find that fishermen who own both instruments or only konou are, respectively, 14 and 23 percentage points less 
Table 3. Determinants of income diversification, marginal effects

\begin{tabular}{|c|c|c|c|c|}
\hline \multicolumn{5}{|c|}{ Panel A: Number of income sources outside the fisheries sector } \\
\hline Degradation & $\begin{array}{c}-1.219^{* * *} \\
(0.148)\end{array}$ & $\begin{array}{l}0.376^{* * *} \\
(0.145)\end{array}$ & $\begin{array}{l}0.335^{* * *} \\
(0.063)\end{array}$ & $\begin{array}{c}0.508 \\
(0.324)\end{array}$ \\
\hline Literacy & $\begin{array}{c}-0.082^{* *} \\
(0.040)\end{array}$ & $\begin{array}{c}0.025 \\
(0.022)\end{array}$ & $\begin{array}{c}0.022 \\
(0.015)\end{array}$ & $\begin{array}{c}0.034^{* *} \\
(0.015)\end{array}$ \\
\hline Ownership acadja/konou & $\begin{array}{c}0.102 \\
(0.067)\end{array}$ & $\begin{array}{c}-0.031 \\
(0.032)\end{array}$ & $\begin{array}{c}-0.028 \\
(0.023)\end{array}$ & $\begin{array}{c}-0.042^{*} \\
(0.025)\end{array}$ \\
\hline Observations & 1,220 & 1,220 & 1,220 & 1,220 \\
\hline \multicolumn{5}{|l|}{ Panel B: Herfindahl index } \\
\hline Degradation & $\begin{array}{c}1.582^{* *} \\
(0.621)\end{array}$ & & & \\
\hline Literacy & $\begin{array}{c}0.028 \\
(0.032)\end{array}$ & & & \\
\hline Ownership acadja/konou & $\begin{array}{c}-0.032 \\
(0.067)\end{array}$ & & & \\
\hline Observations & 1,220 & 1,220 & 1,220 & 1,220 \\
\hline \multicolumn{5}{|c|}{$\begin{array}{l}\text { Notes: }{ }^{* *} p<0.01 ;{ }^{* *} p<0.05 ;{ }^{*} p<0.1 \text {. The coefficients represent marginal } \\
\text { effects calculated after an IV ordered probit regression on the determinants } \\
\text { of the number of income sources (panel A) and an IV tobit regression on } \\
\text { the determinants of the Herfindahl index (panel B). Robust standard errors } \\
\text { are adjusted for clustering by household and are reported in parentheses. In } \\
\text { panel A, columns represent the number of income sources. }\end{array}$} \\
\hline
\end{tabular}

likely to have an income source outside the fisheries sector. The ownership of only acadja is also associated with lower income diversification, but not significantly so (see table A7 in the online appendix). Finally, comparing model estimations with and without controlling for the ownership of acadja or konou, we find that the magnitude and significance level of the degradation coefficient remain largely unchanged (see table A8 in the online appendix). Taken together, these results provide evidence that our estimated effect of degradation on income diversification is not driven by channels 2 or 3 , but by channel 1, i.e., a change in the reservation wage for non-fishing activities.

In the following section, we test how sensitive these findings are to alternative specifications and a series of robustness checks.

\section{Alternative specifications and robustness checks}

\subsection{Alternative measures of degradation}

First, we exploit the fact that we have individual-level information on degradation. Specifically, we estimate equation (1) using individual-level self-reported degradation as a measure for natural resource degradation. Doing so allows us to add village fixed effects and therefore to check the sensitivity of our results to omitted variables at the village level. Table A9 
in the online appendix reports the results of two regressions, one with and the other without village fixed effects. We find that individuals who indicated a decreasing fishing stock are 11 percentage points more likely to have an income source outside the fisheries sector. When adding village fixed effects, the estimate slightly increases to 13 percentage points, indicating that the degradation effect is largely insensitive to omitted variables at the village level. Literate fishermen are found to be 11 percentage points more likely to have an income source outside the fisheries sector, while the owners of acadja or konou are 11 percentage points less likely to diversify their income away from the fisheries sector.

Second, we construct an alternative measure for natural resource degradation using a bio-index. The index was constructed by Gnohossou (2006) who collected information on physicochemical parameters (e.g., temperature, depth, salinity, transparency, oxygen levels) and the presence of aquatic vertebrates from different measuring stations at Lake Nokoué. Based on this information, he conducted a factor analysis and derived a pollution-sensitivity score for all types of aquatic vertebrates based on their presence at the different measuring stations throughout the year. Finally, a bio-index was calculated at the level of the measuring station by taking a weighted sum of the pollution-sensitivity scores of the present aquatic vertebrates. Thirty-four measuring stations are located within our sample area. Using their GPS locations, we calculate a village-level bio-index for the villages located at Lake Nokoué. ${ }^{12}$ The results indicate that a 0.1 unit increase in the bio-index increases the likelihood of having an income source outside the fishing sector by 13 percentage points. Literate fishermen are found to be 19 percentage points more likely to have an income source outside the fishing sector, while the ownership of acadja or konou decreases the likelihood of diversification with 23 percentage points (see table A10 in the online appendix).

\subsection{Representativeness of the sample}

In order to address the concern that our sample may not be representative, we use information from Benin's 2006 fisheries census. The census includes rather crude information on income diversification but has the advantage of a large coverage. This allows us to expand our analysis to 109 villages and 10,850 individuals located in the five communes which border Lake Nokoue - the lake for which the bio-index is available.

As a dependent variable, we construct an indicator variable which takes the value 0 if an individual is a full-time fisher, while it equals 1 if this is not the case. We use Gnohossou's (2006) bio-index to create a commune-level index in ArcGIS. For each commune, we identify the 10 closest measuring stations and use their average score as a commune-level bio-index. We estimate an IV probit model, using distance to the closest influx of water as an instrument for degradation. The results in table 4 confirm our baseline findings. A 0.1 unit increase in the bio-index increases the likelihood of having

12 See section 3.2 in the online appendix for detailed information on Gnohossou's (2006) bio-index. The village-level bio-index ranges from 2.1 to 2.4 with a standard deviation of 0.09 . 
Table 4. Expansion of the analysis using Benin's 2006 fisheries census

\begin{tabular}{lc}
\hline Dependent variable & $I D$ \\
\hline Degradation & $1.269^{* * *}$ \\
& $(0.167)$ \\
Literacy & $0.292^{* * *}$ \\
& $(0.037)$ \\
Ownership acadja/konou & $-0.220^{* * *}$ \\
Observations & $(0.034)$ \\
& 10,850 \\
\hline
\end{tabular}

Notes: ${ }^{* * *} p<0.01 ;{ }^{* *} p<0.05 ;{ }^{*} p<0.1$. This table expands the analysis to 109 villages in the five communes bordering Lake Nokoué (see section 3.3 in the online appendix for detailed information and the full regression output). The coefficients represent marginal effects calculated after an IV probit model on the determinants of income diversification. ID is a dummy variable which takes the value 0 if an individual is a full-time fisher and 1 otherwise.

a diversified income with 13 percentage points. Furthermore, literate individuals are 29 percentage points more likely to diversify their income away from the fishing sector, while individuals who own acadja or konou are 22 percentage points less likely to have a diversified income. ${ }^{13}$

\subsection{Robustness checks}

Finally, we perform a number of robustness checks. The analyses and results are reported in the online appendix. First, we repeat our analysis, using the household rather than the individual as a unit of observation. The results in table A12 indicate that a 10 per cent increase in village-level selfreported degradation is associated with an increase of 1.3 income sources at the $\mathrm{HH}$-level. Second, we run the regression separately for the fishermen and fishmongers in our sample. The results in table A13 indicate that the degradation effect holds to a similar extent for men and for women. Third, the results in tables A14 and A15 show that the estimated marginal effects of degradation on income diversification are hardly affected when additionally controlling for access to credit or the ownership of various assets. Fourth, as our analysis only covers economically active individuals, we use a Heckman (1976) selection model to investigate if our findings are influenced by selection bias. The results in table A17 indicate this is not the case. Finally, the results in table A18 show that our estimate for the degradation effect is robust to using different estimation methods (IV Poisson and 2SLS instead of IV ordered probit and IV tobit).

${ }^{13}$ Figure A2 shows the location of the five communes which border Lake Nokoué. The commune-level bio-index ranges from 1.2 to 2.4 with a standard deviation of 0.25 (see section 3.2 in the online appendix for detailed information). 


\section{Discussion and conclusions}

Severe overfishing has led to a marked decline of the fish stock in southern Benin. In order to curb this declining trend, fishing communities need to alleviate the pressure on the lakes' resources. One way to do so is to diversify income and develop activities outside the fisheries sector.

As hypothesized by Dasgupta (1993), such diversification becomes more attractive as degradation worsens, lowering fishermen's reservation wage for outside employment. Testing this hypothesis for fishing communities in southern Benin, we find that fishermen are more likely to reallocate labour towards activities outside the fishing sector in areas where natural resource degradation is more severe, a result that remains throughout a number of robustness checks and when controlling for a large number of individual-, household- and village-level covariates. The result also holds when: (i) instrumenting degradation using distance to the closest influx of water; (ii) using a bio-index to measure degradation rather than selfreported degradation; and (iii) using a larger sample of households from the 2006 census.

Although we find support for Dasgupta's hypothesis, the level of diversification away from the fisheries sector remains low and far from sufficient to relieve the stress on the lakes. Fishing communities in our sample remain extremely dependent on the local fish stock, with fishing activities contributing up to 80 per cent of annual income. Such dependency continues to put pressure on the lakes. Without access to attractive outside options, there may be a real danger for these fishing communities to fall into a poverty-environment trap. We find indications that the limited levels of diversification stem from the lack of effective institutions to manage the commons, and the limited access to attractive outside options for a large part of our sample. Indeed, the level of income diversification is especially weak for fishermen that use productive, but highly damaging, fishing gear and for illiterate fishermen.

Our analysis thus confirms the importance of education for diversification, showing that higher educational attainment leads to higher levels of income diversification. Schooling levels in our sample are however very low, with 70 per cent of our respondents being illiterate. In future research we aim to look more in depth at the relationship between degradation and investment in schooling. So far, the data show that younger generations are increasingly attending school. This is especially the case in villages with higher levels of degradation. From interviews with fishermen, we know that parents used to keep their children from school in order to train them as fishers from a young age. As the continuing degradation of the fish stock and the associated decline in fishing revenues decrease the attractiveness of fishing activities, parents seem to become more eager to send their children to school. Since educational attainment is positively related to income diversification, this may indicate a potential 'generational effect' of resource degradation on income diversification, mediated by schooling.

Benin's 2011 poverty reduction strategy paper explicitly aims to link the sustainable use of natural resources, including inland fisheries, to poverty reduction (OECD, 2012). In that respect, our findings suggest that policy 
makers should promote economic activities outside the fisheries sector, e.g., by stimulating entrepreneurship through micro-credit programmes, improving transportation networks, and promoting education. In particular, functional schooling and specific vocational training may help fishermen to access microfinance and digital technologies (such as satellite navigation, mobile phones and the internet) (FAO, 2001). At the same time, the use of highly productive but damaging fishing instruments needs to be discouraged by effective regulation and monitoring. Such a two-track policy could enhance the fishermen's access to attractive outside options, and safeguard fishing communities from a poverty-environment trap.

\section{References}

Allan, J.D., R. Abell, Z. Hogan, C. Revenga, B.W. Taylor, R.L. Welcomme, and K. Winemiller (2005), 'Overfishing of inland waters', BioScience 55(12): 1041.

Amoussou, E. (2004), 'Systèmes traditionnels de gestion durable du lac Ahémé au Bénin', Développement durable: leçons et perspectives, Quebec: L'Agence universitaire de la Francophonie, pp. 263-270.

Atti-Mama, C. (1998), 'Co-management in continental fishing in Benin: the case of Lake Nokoué', Paper presented at the International Workshop on Fisheries Co-Management, November, Maputo, Mozambique.

Barbier, E.B. (2007), 'Natural capital and labor allocation mangrove-dependent households in Thailand', Journal of Environment and Development 16(4): 398-431.

Barbier, E.B. (2010), 'Poverty, development, and environment', Environment and Development Economics 15(6): 635-660.

Barrett, C.B. and T. Reardon (2000), 'Asset, activity, and income diversification among African agriculturalists: some practical issues', Working Paper No. 14734, Department of Applied Economics and Management, Cornell University, Ithaca, New York.

Barrett, C.B., T. Reardon, and P. Webb (2001), 'Nonfarm income diversification and household livelihood strategies in rural Africa: concepts, dynamics, and policy implications', Food Policy 26(4): 315-331.

Briones Alonso, E., M. Verpoorten, and R. Houssa (forthcoming), 'Voodoo versus fishing committees: the role of traditional and contemporary institutions in fisheries management', Ecological Economics.

Cinner, J.E., M.A. MacNeil, X. Basurto, and S. Gelcich (2013), 'Looking beyond the fisheries crisis: cumulative learning from small-scale fisheries through diagnostic approaches', Global Environmental Change 23(6): 1359-1365.

Clark, G. (1994), Onions Are My Husband: Survival and Accumulation by West African Market Women, Chicago, IL: University of Chicago Press.

Cledjo, P. (2006), 'Genre de vie et problèmes environnementaux du lac Nokoué', PhD thesis, University of Abomey-Calavi, Benin.

Dangbégnon, C. (2000), 'Governing local commons: what can be learned from the failures of Lake Ahémé's institutions in Benin?', Paper presented at the Eighth Biennial Conference of the International Association for the Study of Common Property, Bloomington, IN.

Dasgupta, P. (1993), An Inquiry Into Well-Being and Destitution, Oxford: Oxford University Press.

Doss, C.R. (2001), 'Is risk fully pooled within the household? Evidence from Ghana', Economic Development and Cultural Change 50(1): 101-130. 
Ellis, F. (1999), 'Rural livelihood diversity in developing countries: evidence and policy implications', ODI Natural Resources Perspectives No. 40, Overseas Development Institute, London.

Ellis, F. and E. Allison (2004), 'Livelihood diversification and natural resource access', LSP Working Paper No. 9, Food and Agricultural Organisation of the United Nations, Rome.

Ernst, B., J. Chamorro, P. Manríquez, J.M.L. Orensanz, A.M. Parma, J. Porobic, and C. Román (2013), 'Sustainability of the Juan Fernández lobster fishery (Chile) and the perils of generic science-based prescriptions', Global Environmental Change 23(6): 1381-1392.

Falen, D. (2003), 'Paths of power: control, negotiation and gender among the Fon of Benin', PhD thesis, University of Pennsylvania, Philadelphia, PA.

FAO (2001), Sustainable Fisheries Livelihoods Programme - New Directions in Fisheries, Food and Agricultural Organisation of the United Nations, Rome.

FAO (2008), Vue générale du secteur des pêches national - La République du Bénin, Food and Agricultural Organisation of the United Nations, Rome.

Forsyth, T., M. Leach, and T. Scoones (1998), 'Poverty and environment: priorities for research and study - an overview study', prepared for United Nations Development Programme, New York and European Commission, Brussels.

Gnohossou, P.M. (2006), 'La faune benthique d'une lagune ouest africaine (le lac Nokoué au Benin), diversité, abondance, variations temporelles et spatiales, place dans la chaine tropique', PhD thesis, Institut Polytechnique de Toulouse, Toulouse, France.

Heckman, J. (1976), 'The common structure of statistical models of truncation, sample selection and limited dependent variables and a simple estimator for such models', Annals of Economic and Social Measurement 5(4): 475-492.

Houssa, R. and M. Verpoorten (2015), 'The unintended consequence of an export ban: evidence from Benin's shrimp sector', World Development 67: 138-150.

Lanjouw, P., J. Quizon, and R. Sparrow (2001), 'Non-agricultural earnings in periurban areas of Tanzania: evidence from household survey data', Food Policy 26(4): 385-403.

LeMay-Boucher, P. and O. Dagnelie (2012), 'The divorced financial spheres of Beninese spouses', Journal of International Development 26(1): 46-58.

Maarleveld, M. and C. Dangbégnon (1999), 'Managing natural resources: a social learning perspective', Agriculture and Human Values 16: 267-280.

MacNeil, M. and J.E. Cinner (2013), 'Hierarchical livelihood outcomes among comanaged fisheries', Global Environmental Change 23: 1393-1401.

Mandel, J.L. (2006), 'Creating profitable livelihoods: mobility as a "practical" and "strategic" gender need in Porto Novo, Benin', Journal of Economic and Social Geography 97: 343-363.

Moulton, B.R. (1990), 'An illustration of a pitfall in estimating the effects of aggregate variables on micro unit', Review of Economics and Statistics 72(2): 334-338.

Niyonkuru, C. and P.A. Lalèyè (2010), 'Impact of acadja fisheries on fish assemblages in Lake Nokoué, Benin, West Africa', Knowledge and Management of Aquatic Ecosystems 339: 1-15.

OECD (2012), 'Strategic environmental assessment in development practice a review of recent experience', Organisation for Economic Cooperation and Development, Paris.

Pascual, U. and E.B. Barbier (2006), 'Deprived land-use intensification in shifting cultivation: the population pressure hypothesis revisited', Agricultural Economics 34(2): 155-165.

Pascual, U. and E.B. Barbier (2007), 'On price liberalization, poverty, and shifting cultivation: an example from Mexico', Land Economics 83(2): 192-216. 
Pliya, J. (1980), La pêche dans le Sud-Oest du Bénin. Etude de géographie appliquée sur la partie continentale et maritime, Paris: AGECOOP.

Reardon, T. and S.A. Vosti (1995), 'Links between rural poverty and the environment in developing countries: asset categories and investment poverty', World Development 23(9): 1495-1506.

Roche International (2000), Etude du Projet d'Amenagement des Plan d'Eau du Sud Benin, Quebec: Roche International.

Smith, D.R., A. Gordon, K. Meadows, and K. Zwick (2001), 'Livelihood diversification in Uganda: patterns and determinants of change across two rural districts', Food Policy 26(4): 421-435.

Swinton, S.M., G. Escobar, and T. Reardon (2003), 'Poverty and environment in Latin America: concepts, evidence and policy implications', World Development 31(11): 1865-1872.

Udry, C. (1996), 'Gender, agricultural production, and the theory of the household', Journal of Political Economy 104(5): 1010-1046.

USAID (2007), Biodiversity and Tropical Forest Assessment for Benin, Washington, DC: USAID.

WCED (World Commission on Environment and Development) (1987), Our Common Future, Oxford: Oxford University Press. 